\title{
Protein expression of the Ets transcription factor Elf-1 in breast cancer cells is negatively correlated with histological grading, but not with clinical outcome
}

\author{
ALICE GERLOFF $^{1}$, ANGELA DITTMER ${ }^{1}$, ILKA OERLECKE ${ }^{1}$, \\ HANS-JÜRGEN HOLZHAUSEN ${ }^{2}$ and JÜRGEN DITTMER ${ }^{1}$ \\ ${ }^{1}$ Klinik für Gynäkologie, ${ }^{2}$ Institut für Pathologie, Universität Halle, Halle/Saale, Germany
}

Received May 30, 2011; Accepted July 1, 2011

DOI: 10.3892/or.2011.1409

\begin{abstract}
Several members of the Ets (E26 transformation specific) transcription factor family are involved in tumor progression, e.g. by activating matrix metalloproteases. Ets proteins share a unique DNA-binding domain, the Ets domain, which specifically recognizes GGAA/T-containing sequences common in many promoters. While the roles of quite a number of Ets proteins in carcinogenesis have been well established, little is known about the importance of the Ets protein Elf-1 (E74-like factor 1) in cancer. Herein, we analyzed the expression of Elf-1 in breast cancer. We found that, like T-cells, breast cancer cells express both the 80 and $98 \mathrm{kDa}$ isoforms of the Elf-1 protein with the $98 \mathrm{kDa}$ isoform only be present in the nucleus. Immunohistochemical analysis of 119 breast cancer biopsies showed anti-Elf-1 immunoreactivity exclusively in the nucleus. Elf-1 expression varied largely among the breast cancer samples showing a negative correlation with histological grading. However, no association of Elf-1 expression with clinical outcome was observed, even when sub-cohorts of patients who received either only adjuvant endocrine treatment or only chemotherapy were separately analyzed. These data suggest that Elf-1 may modulate breast cancer progression to some extent without having an impact on survival of breast cancer patients.
\end{abstract}

\section{Introduction}

Elf-1 is a member of the Ets transcription factor family that comprises more than 20 members (1-3). Ets transcription factors share a unique DNA-binding domain, the Ets domain, which allows these proteins to bind to sequences containing a GGAA/T core motif. Many genes harbor Ets binding sites

Correspondence to: Dr Jürgen Dittmer, Klinik für Gynäkologie, Universität Halle, Ernst-Grube-Str. 40, 06120 Halle/Saale, Germany E-mail: juergen.dittmer@medizin.uni-halle.de

Key words: E26 transformation specific proteins, Elf-1, breast cancer, prognosis, grading and are responsive to Ets proteins (4). In vitro, gene promoters can often be activated by more than one Ets protein. A study on T-cells combining chromatin immunoprecipation with cDNA microarray (ChIP-CHIP) revealed that, also in vivo, many promoters are redundantly occupied by more than one Ets protein (5). This raises the question of how specificity of Ets-dependent gene expression is achieved. It is thought that expression pattern, post-translational modifications, preferences for cooperating transcription factors and the sequence flanking the core binding motif are major factors that determine which Ets factor regulates which genes under certain conditions (6-8). Elf-1 often shares promoter sequences with Ets1, the founding member of the Ets family. Of note, knock-out of either Elf-1 or Ets1 in mice led to anomalities in the development of natural killer T-cells $(9,10)$. Both Elf-1 and Ets1 are also found in tumor cells. While the tumor-promoting function of Ets1 is well established (reviewed in refs. 2,11), only a few studies have yet been undertaken to analyze the role of Elf-1 in tumor progression. For example, in ovarian and endometrial cancer, Elf-1 expression correlates with poor prognosis (12-14). In melanoma, Elf-1 seems to be involved in tumor-induced neo-angiogenesis (14) and, in breast cancer, Elf-1 was found to be a major factor driving the tumor-promoter gene Pygopus2 (15).

As a transcription factor Elf-1 is mainly located in the nucleus (16), but also resides in the cytoplasm, where it can bind to underphosphorylated retinoblastoma protein $(\mathrm{Rb})(17)$. Release from this complex seems to require post-translational modifications, such as O-linked glycosylation and phosphorylation (18). This modification leads to a change in the apparent molecular weight of the Elf-1 protein from 80 to $98 \mathrm{kDa}$. The $98 \mathrm{kDa}$ form of Elf-1 is exclusively found in the nucleus suggesting that upon its release from Rb Elf-1 translocates to the nucleus. Loss of the ability of T-cells to produce the $98 \mathrm{kDa}$ Elf-1 form has been linked to decreased expression of T-cell receptor $\zeta$ and systemic lupus erythematosus (19). O-linked glycosylation of Elf-1 may also regulate its ability to interact with other transcription factors. For example, O-linked $\mathrm{N}$-acetylglucosamination of Elf-1 was found to inhibit its physical and functional interaction with Sp1 (20).

In breast cancer, increased Ets1 expression has been linked to poor prognosis (21), whereas, to our knowledge, 
A
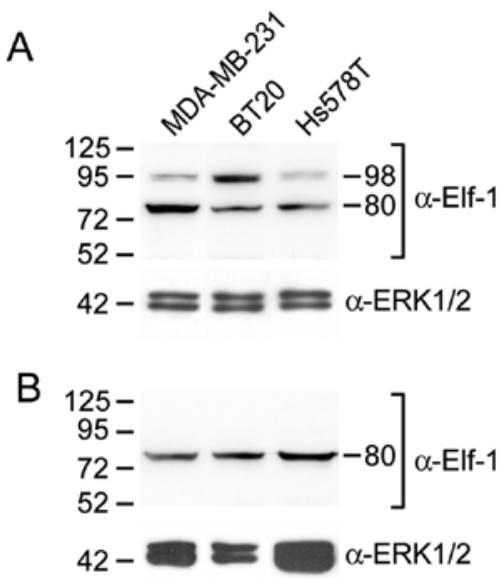

C

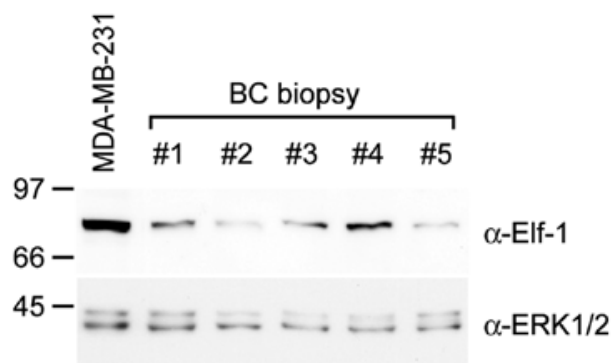

Figure 1. Breast cancer cells express Elf-1. Nuclear (A) and cytosolic (B) extracts of breast cancer cell lines and cytosolic extracts from breast cancer (BC) biopsies (C) were examined for their abundance of Elf-1 protein isoforms by Western blot analysis.

the importance of Elf-1 expression on the outcome of breast cancer patients has not yet been investigated. In the present study, we analyzed Elf- 1 expression immunohistochemically in specimens of breast cancer patients. While we did not find a correlation with prognosis, we observed that Elf-1 expression was negatively associated with histological grading.

\section{Material and methods}

Cell lines, protein extraction and Western blot analysis. MDA-MB-231, Hs578T and BT20 breast cancer cells were maintained in RPMI medium (Gibco-Invitrogen) supplemented with $10 \%$ fetal calf serum (PAN) in the absence of antibiotics. For the extraction of cytoplasmic and nuclear proteins, cells were harvested and subjected to treatment with low and high salt buffers as described (22). Extraction of cytosolic proteins from breast cancer tissues was performed according to Schunke et al (23). Western blot analysis was carried out as described (24). For the detection of Elf-1, a rabbit polyclonal Elf-1 specific antibody (Santa Cruz Biotechnology, C-20) was used at a final dilution of 1:2,000. To control for equal protein loading, a rabbit polyclonal ERK1/2 specific antibody (Cell Signalling Technology) was applied (dilution 1:1,000) (25). The anti-rabbit antibody horseradish peroxidase-conjugate was purchased from Cell Signalling Technology. Peroxidase activity was visualized by chemiluminescence by using ECL-Plus and Hyperfilm ECL (GE-Amersham).

Table I. Comparison of Elf-1 expression with clinicopathological data.

\begin{tabular}{llll}
\hline Variable & $\begin{array}{c}\text { No. of } \\
\text { cases }\end{array}$ & $\begin{array}{c}\text { Cases of Elf-1 } \\
\text { expression (\%) }\end{array}$ & P-value \\
\hline
\end{tabular}

Age (years)
$<50$
$\geq 50$

26

70

$16(61.5)$

$44(62.9)$

Nodal status

$\begin{array}{llll}\text { N0 } & 60 & 40(66.7) & 0.28 \\ \text { N1 } & 36 & 20(55.6) & \end{array}$

Tumor size

\begin{tabular}{lrrr} 
pT1 & 43 & $31(72.1)$ & \\
pT2 & 43 & $24(55.8)$ & 0.20 \\
pT3/4 & 10 & $5(50.0)$ & \\
Grading & & & \\
G1 & 3 & $3(100.0)$ & \\
G2 & 49 & $36(73.5)$ & 0.015 \\
G3 & 44 & $21(47.7)$ & \\
ER $^{\mathrm{b}}$ & & & \\
Negative & 37 & $22(59.5)$ & 0.67 \\
Positive & 58 & $37(63.8)$ & \\
PR $^{\mathrm{b}}$ & & & \\
Negative & 54 & $36(66.7)$ & 0.29 \\
Positive & 41 & $23(56.1)$ & \\
Her2/neu & & & \\
Negative & 27 & $18(66.7)$ & 0.78 \\
Positive & 16 & $10(62.5)$ & \\
\hline
\end{tabular}

${ }^{a}$ Values were calculated by cross table analysis using the $\chi^{2}$ test. ${ }^{b} \mathrm{Not}$ all samples were measured for this factor.
Immunohistochemistry. Formaldehyde-fixed paraffinized breast cancer samples were cut into sections which were subjected to deparaffinization, peroxidase blocking, demasking and antibody treatment as described previously (26). The Elf-1 specific antibody was used at a final dilution of 1:200. Quantitation of the staining signals in tumor cell nuclei were carried out by using the immunoreactive score (IRS). Calculation of the IRS was performed as described (26). Breast cancer sections with an IRS $>2$ were considered to be Elf-1 positive.

Breast cancer biopsies. Breast cancer biopsies from 119 patients who were diagnosed with breast cancer in 1999 or 2000 were used for Elf-1 expression analyses. Of these biopsies, 96 were invasive ductal carcinoma, 6 lobular carcinomas and 17 other types of breast cancer lesions. This study was approved by the Institutional Review Board.

Statistical methods. Cross table analyses comparing Elf-1 nuclear staining with clinicopathological data were carried by using $\chi^{2}$ test. $\mathrm{P}<0.05$ were considered to be statistically signifi- 

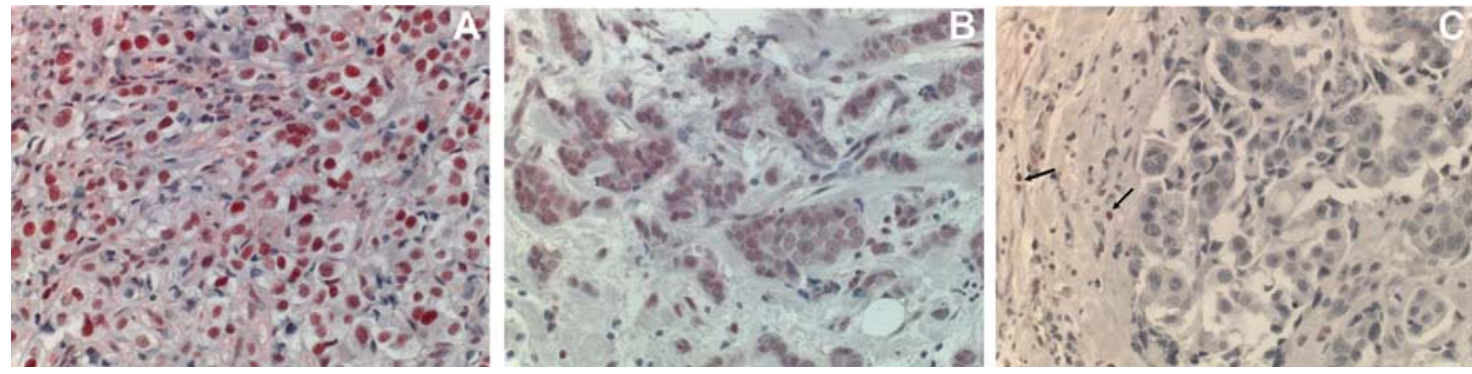

Figure 2. Nuclear immunoreactivity to the Elf-1 antibody varies among breast cancer samples. Sections of breast cancer samples were immunohistochemically stained for Elf-1. Samples with different staining activities (A, IRS=9; B, IRS=2; C, IRS=0; arrows indicate Elf-1 expressing lymphocytes) are shown.
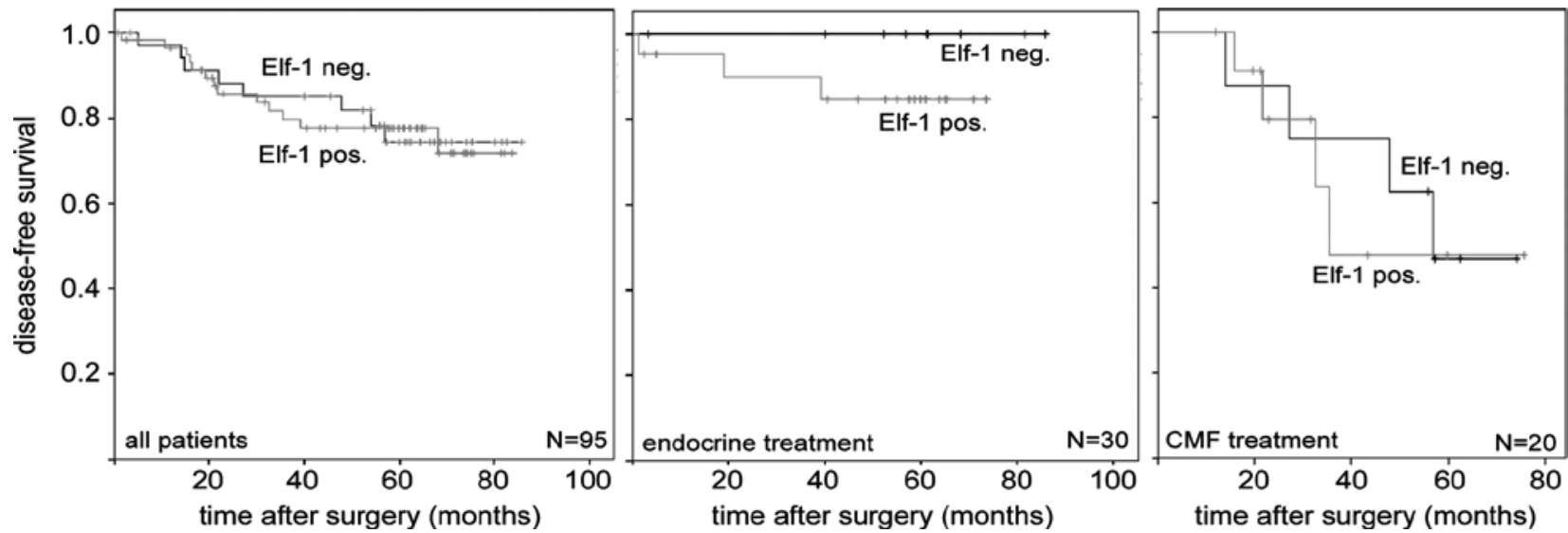

Figure 3. Immunoreactivity to Elf-1 is not linked to clinical outcome of breast cancer patients. Kaplan-Meier survival curves are shown for the cohort of 95 patients with invasive ductal carcinoma and for subpopulations of these patients who either received endocrine therapy only or who were treated with CMF only.

cant. The Kaplan-Meier method was applied for calculating survival probabilities.

\section{Results}

Breast cancer cells express both the 80 and $98 \mathrm{kDa}$ Elf- 1 isoforms. We examined Elf-1 protein expression in three breast cancer cell lines, MDA-MB-231, Hs578T and BT20, by Western blot analysis. In all three cell lines, the 80 and $98 \mathrm{kDa}$ Elf-1 isoform could be detected in nuclear protein extracts (Fig. 1A). However, the ratio of the 98 to the $80 \mathrm{kDa}$ isoform varied among the cell lines. In BT20 cells, the $98 \mathrm{kDa}$ isoform was more prominent, whereas in the other two cell lines, the $80 \mathrm{kDa}$ isoform was more abundant. In contrast to the nucleus, the cytoplasma contained only the $80 \mathrm{kDa}$ Elf- 1 isoform (Fig. 1B). This shows that Elf-1 protein is expressed in different breast cancer cell lines and that, similar to T-cells (18), breast cancer cells express the $98 \mathrm{kDa}$ isoform only in the nucleus. We next examined protein extracts from primary breast cancer specimens for Elf-1 protein expression by Western blot analysis. The $80 \mathrm{kDa}$ Elf-1 protein band, but not the $98 \mathrm{kDa}$ band could be visualized. Since other nuclear proteins, such as Ets1, could not be detected either (data not shown) it is likely that the Triton X-based extraction procedure used here did not allow the extraction of nuclear proteins in sufficient amounts. Nevertheless, the data show that Elf-1 protein is also present in primary breast cancer.
NuclearexpressionofElf-1 negativelycorrelateswith histological grading. We next analyzed sections from formaldehyde-fixed, paraffinized samples of 119 breast cancer patients by immunohistochemical staining using an anti-Elf-1 antibody. Of the 119 breast cancers, 96 were ductal carcinomas, 6 lobular carcinomas and 17 other types of breast tumors. Incubation with the Elf-1 specific antibody resulted exclusively in nuclear staining of tumor cells whereby the staining intensity varied strongly among tumor samples (Fig. 2). In all sections, lymphocytes showed intense staining in response to the Elf- 1 antibody and could therefore be used as a positive control for the staining reaction. Of the ductal carcinomas, $61.9 \%$ stained positive for Elf-1, all 6 lobular carcinomas expressed Elf-1 and, of the other breast tumors, $84.6 \%$ were Elf-1 positive.

We next compared Elf-1 expression in tumor cell nuclei with clinicopathological data, including age, nodal status, tumor size, histological grading, hormone receptor status and Her2 status. This analysis was restricted to the ductal carcinoma group to which most of the cases belonged. By using the $\chi^{2}$-test for statistical analysis, we found that Elf-1 nuclear expression negatively correlates with histological grading in a significant manner (Table I): all three G1 tumors showed Elf-1 expression, $\sim 74 \%$ of the G2 tumors expressed Elf- 1 and only 48\% of the G3 tumors displayed anti-Elf-1 antibody reactivity. A tendency, though not statistically significant, was also found when Elf-1 expression was compared with tumor size. At T1, 72\% of the breast cancers showed Elf-1-specific 
staining, which decreased to $\sim 56 \%$ at $\mathrm{T} 2$ and further declined to $\sim 50 \%$ in the T3/T4 group. The negative correlation between Elf-1 expression and histological grade and to some extent also with tumor size may suggest that Elf-1 expression in breast cancer cases with tumor progression.

Tumoral Elf-1 expression is not associated with clinical outcome of breast cancer patients. We next explored the possiblity that Elf-1 expression may be associated with clinical outcome of breast cancer patients. By using Kaplan-Meier statistics we found that Elf-1 expression in breast cancer cells had no effect on disease-free survival (Fig. 3). Since the patients were treated differently, we also tested whether Elf-1 expression correlates with survival within a subpopulation of patients who either received adjuvant endocrine or adjuvant CMF (cyclophosphamide, methotrexate and 5-fluorouracil) therapy. However, in neither subpopulation was Elf-1 expression linked to clinical outcome. This suggests that, despite its negative correlation with grading, Elf-1 protein expression has no predictive value in breast cancer.

\section{Discussion}

Several Ets transcription factors are linked to cancer. Among them are Ets1, Ets2, Fli-1, Esx, Ese-1, ERM, PEA-3 and ER81 $(2,3,11,27,28)$. Evidence has been accumulated that these proteins are involved in important key processes, such as invasion, that drive tumor progression. Among the tumor-relevant target genes of Ets proteins are matrix metalloproteases, transforming growth factor receptor II and human epidermal growth factor receptor 2 (29-31). To some extent, Ets proteins may be functionally redundant, which has been specifically discussed for Ets1 and Ets2 (32). Redundant occupation of Ets target genes in T-cells by Ets1 and Elf-1 may also suggest partial functional redundancy of these two proteins (5).

However, herein we show that despite the correlation between Ets1 expression and unfavorable prognosis of breast cancer patients as has been reported previously (21), there is no association between Elf-1 expression and the clinical outcome of patients suffering from invasive ductal breast carcinoma. Even if subpopulations of patients who received adjuvant endocrine or CMF treatment were selectively analyzed, no link between Elf-1 expression and outcome could be observed. However, Elf-1 nuclear staining was found to be negatively associated with histological grading and, to some extent, also with tumor size. This may suggest that Elf-1 expression is reduced with the progression of breast cancer. It may be that other Ets factors, such as Ets1, Ets2 or Ese-1, are more efficient than Elf-1 in activating tumor-relevant genes and may therefore be more important for breast cancer progression. In support of this notion, we found that Ets1, Ets2 and Ese-1 had a much stronger supporting effect on phorbol ester-driven expression of tumor-relevant PTHrP (parathyroid hormone-related protein) gene than Elf-1 (33). If Elf-1 has a lower potential than Ets1 or other Ets transcription factors to activate genes that are required for tumor progression, it is possible that Elf-1 by competing with Ets1 and other Ets factors may slow down tumor progression. This would explain why Elf-1 expression is lower, when tumor grading and tumor size increase.
Interestingly, immunohistochemical studies on ovarian and endometrial cancers, in which the same Elf- 1 antibody had been used as in our study, Elf-1 expression was found to rather correlate positively with histological grading and to be associated with unfavorable clinical outcome $(12,13)$. This suggests that Elf-1 may have different functions in different cancer types. Since Ets proteins largely depend on cooperating transcription factors for activity (34), it may be that tumor type-dependent differences in the expression of transcription factors that interact with Elf-1 are responsible for these differences.

\section{Acknowledgements}

This study was supported by DLR/BMBF grant NBL-3/ FKZ5/14.

\section{References}

1. Dittmer $\mathrm{J}$ and Nordheim A: Ets transcription factors and human disease. Biochim Biophys Acta 1377: F1-F11, 1998.

2. Seth A and Watson DK: ETS transcription factors and their emerging roles in human cancer. Eur J Cancer 41: 2462-2478, 2005.

3. Foos $\mathrm{G}$ and Hauser $\mathrm{C}$ : The role of Ets transcription factors in mediating cellular transformation. In: Handbook of Experimental Pharmacology. Gossen M, Kaufmann J and Triezenberg SJ (eds). Vol. 166, Springer, Heidelberg, pp259-275, 2004.

4. Sementchenko VI and Watson DK: Ets target genes: past, present and future. Oncogene 19: 6533-6548, 2000.

5. Hollenhorst PC, Shah AA, Hopkins C and Graves BJ: Genomewide analyses reveal properties of redundant and specific promoter occupancy within the ETS gene family. Genes Dev 21: 1882-1894, 2007.

6. Hollenhorst PC, Chandler KJ, Poulsen RL, Johnson WE, Speck NA and Graves BJ: DNA specificity determinants associate with distinct transcription factor functions. PLoS Genet 5: e1000778, 2009.

7. Tootle TL and Rebay I: Post-translational modifications influence transcription factor activity: A view from the ETS superfamily. Bioessays 27: 285-298, 2005.

8. Oikawa T and Yamada T: Molecular biology of the Ets family of transcription factors. Gene 303: 11-34, 2003.

9. Walunas TL, Wang B, Wang CR and Leiden JM: Cutting edge: the Ets1 transcription factor is required for the development of NK T cells in mice. J Immunol 164: 2857-2860, 2000.

10. Choi HJ, Geng Y, Cho H, Li S, Giri PK, Felio K and Wang CR: Differential requirements for the Ets transcription factor Elf-1 in the development of NKT cells and NK cells. Blood 117: 1880-1887, 2011.

11. Dittmer J: The Biology of the Ets1 Proto-Oncogene. Mol Cancer 2: 29,2003

12. Takai N, Miyazaki T, Nishida M, Shang S, Nasu K and Miyakawa I: Clinical relevance of Elf-1 overexpression in endometrial carcinoma. Gynecol Oncol 89: 408-413, 2003.

13. Takai N, Miyazaki T, Nishida M, Nasu K and Miyakawa I: The significance of Elf-1 expression in epithelial ovarian carcinoma. Int J Mol Med 12: 349-354, 2003.

14. Huang X, Brown C, Ni W, Maynard E, Rigby AC and Oettgen P: Critical role for the Ets transcription factor ELF-1 in the development of tumor angiogenesis. Blood 107: 3153-3160, 2006.

15. Andrews PG, Kennedy MW, Popadiuk CM and Kao KR: Oncogenic activation of the human Pygopus 2 promoter by E74-like factor-1. Mol Cancer Res 6: 259-266, 2008.

16. Bredemeier-Ernst I, Nordheim A and Janknecht R: Transcriptional activity and constitutive nuclear localization of the ETS protein Elf-1. FEBS Lett 408: 47-51, 1997.

17. Wang CY, Petryniak B, Thompson CB, Kaelin WG and Leiden JM: Regulation of the Ets-related transcription factor Elf-1 by binding to the retinoblastoma protein. Science 260 : 1330-1335, 1993

18. Juang YT, Solomou EE, Rellahan B and Tsokos GC: Phosphorylation and O-linked glycosylation of Elf-1 leads to its translocation to the nucleus and binding to the promoter of the TCR zeta-chain. J Immunol 168: 2865-2871, 2002. 
19. Juang YT, Tenbrock K, Nambiar MP, Gourley MF and Tsokos GC: Defective production of functional 98-kDa form of Elf-1 is responsible for the decreased expression of TCR zetachain in patients with systemic lupus ery thematosus. J Immunol 169: 6048-6055, 2002.

20. Lim K and Chang HI: O-GlcNAc inhibits interaction between Sp1 and Elf-1 transcription factors. Biochem Biophys Res Commun 380: 569-574, 2009.

21. Span PN, Manders P, Heuvel JJ, Thomas CM, Bosch RR, Beex LV and Sweep CG: Expression of the transcription factor Ets-1 is an independent prognostic marker for relapse-free survival in breast cancer. Oncogene 21: 8506-8509, 2002.

22. Dittmer A, Hohlfeld K, Lutzkendorf J, Muller LP and Dittmer J: Human mesenchymal stem cells induce E-cadherin degradation in breast carcinoma spheroids by activating ADAM10. Cell Mol Life Sci 66: 3053-3065, 2009.

23. Schunke D, Span P, Ronneburg H, Dittmer A, Vetter M, Holzhausen HJ, Kantelhardt E, Krenkel S, Muller V, Sweep FC, Thomssen C and Dittmer J: Cyclooxygenase-2 is a target gene of rho GDP dissociation inhibitor beta in breast cancer cells. Cancer Res 67: 10694-10702, 2007.

24. Dittmer A, Vetter M, Schunke D, Span PN, Sweep F, Thomssen C and Dittmer J: Parathyroid hormone-related protein regulates tumor-relevant genes in breast cancer cells. J Biol Chem 281: 14563-14572, 2006.

25. Dittmer A and Dittmer J: Beta-actin is not a reliable loading control in Western blot analysis. Electrophoresis 27: 2844-2845, 2006.

26. Ronneburg H, Span PN, Kantelhardt E, Dittmer A, Schunke D, Holzhausen HJ, Sweep FC and Dittmer J: Rho GDP dissociation inhibitor $\alpha$ expression correlates with the outcome of CMF treatment in invasive ductal breast cancer. Int J Oncol 36: $379-386,2010$
27. Hsu T, Trojanowska $M$ and Watson DK: Ets proteins in biological control and cancer. J Cell Biochem 91: 896-903, 2004.

28. de Launoit Y, Baert JL, Chotteau-Lelievre A, Monte D, Coutte L, Mauen S, Firlej V, Degerny C and Verreman K: The Ets transcription factors of the PEA3 group: transcriptional regulators in metastasis. Biochim Biophys Acta 1766: 79-87, 2006.

29. Oikawa T: ETS transcription factors: possible targets for cancer therapy. Cancer Sci 95: 626-633, 2004.

30. Kopp JL, Wilder PJ, Desler M, Kim JH, Hou J, Nowling T and Rizzino A: Unique and selective effects of five Ets family members, Elf3, Ets1, Ets2, PEA3, and PU.1, on the promoter of the type II transforming growth factor-beta receptor gene. J Biol Chem 279: 19407-19420, 2004

31. Benz CC, O'Hagan RC, Richter B, Scott GK, Chang CH, Xiong X, Chew K, Ljung BM, Edgerton S, Thor A and Hassell JA: HER2/ Neu and the Ets transcription activator PEA3 are coordinately upregulated in human breast cancer. Oncogene 15: 1513-1525, 1997.

32. Oettgen P: Functional redundancy of Ets1 and Ets2. Blood 114: 934-935, 2009.

33. Lindemann RK, Braig M, Hauser CA, Nordheim A and Dittmer J: Ets2 and PKCepsilon are important regulators of parathyroid hormone-related protein expression in MCF-7 breast cancer cells. Biochem J 372: 787-797, 2003.

34. Crepieux P, Coll J and Stehelin D: The Ets family of proteins: weak modulators of gene expression in quest for transcriptional partners. Crit Rev Oncog 5: 615-638, 1994. 